\title{
The Institutional Framework for Implementation of State National Policy of the Russian Federation
}

\author{
Inna Plyugina, and Zhanna Gaunova \\ The Institute of Legislation and Comparative Law under the Government of the Russian Federation, \\ B. Cheremushkinskaya Street, bldg. 34, 117218 Moscow, Russian Federation
}

\begin{abstract}
The implementation of State National Policy of the Russian Federation, the achievement of the set strategic goals and objectives in the field of inter-ethnic relations necessitates combining the efforts of public authorities at various territorial levels. In general, it can be stated that the institutional framework required to ensure the State National Policy of the Russian Federation has generally been formed to this date. Mechanisms for interaction between public authorities involved in the implementation of national policy are further developed; the formation of the uniform institutional framework in the field of interethnic relations at the federal, regional and municipal levels continues; the practice of interaction between public authorities and civil society institutions expands. Apart from that and despite significant achievements, it has not yet been possible to adequately coordinate the activities of all implementers. There are issues in the use of certain institutional instruments at the regional and municipal levels caused by the insufficient elaboration of the corresponding legal framework
\end{abstract}

\section{Introduction}

The Russian Federation is one of the largest multinational states according to the 2010 AllRussian Population Census, over 190 nationalities live on its territory. This predetermines the main priorities of the State National Policy of the Russian Federation (hereinafter referred to as "The National Policy") [7]. Within the literature is noted that in the last three decades in the Russian Federation there is a process that can be called "ethnic revival" and at the same time the formation of a multiethnic civil nation of Russians; it was this path that was chosen to achieve the goal of the national policy aimed at strengthening the all-Russian civic identity while preserving the ethnocultural diversity of the peoples of the Russian Federation [6].

The National Policy efficiency is largely determined by the well-built system of public authorities, active participation in its implementation of local self-government bodies, a clear division of their tasks and functions, coordination of actions with civil society institutions for the implementation of measures aimed at achieving the set strategic goals and objectives. The multilevel approach to the formation of the institutional framework is predetermined by both the federal nature of the state territorial structure and the complex ethnic composition of the population of the regions; It is this factor that determines the predominant use of methods of decentralized state administration in the field of interethnic relations, which, in turn, 
presupposes a high degree of independence of the state authorities of the constituent entities of the Russian Federation. However, this approach presupposes the creation of effective mechanisms for the coordination and interaction of all entities involved in the implementation of national policy.

As noted in the literature, many aspects of ethnonational relations are far from being constantly available to the direct regulatory influence of state bodies, in this regard, the cooperation of authorities with civil society institutions representing certain ethnic groups: associations, communities, national-cultural autonomies, non-profit organizations of the ethnocultural profile is of particular importance [2].

\section{Materials and Methods}

The methodology consisted of general and special scientific knowledge methods: the formallogical method, which includes analysis and synthesis, induction and deduction, abstraction and generalization, analogy and comparison; systemic and structural method; formal legal method; comparative legal method; method of special legal research; methods of interpretation of the law, including lexical, systematic, doctrinal and authentic ways; content analysis; method of legal forecasting, etc. The special legal research method helps to identify the main directions of optimization of the institutional mechanism for ensuring the state nationality policy of the Russian Federation, to assess the role of strategic planning in its formation. The development of the set goals and objectives was carried out on the basis of a systemic and structural analysis of the regulatory legal acts of the Russian Federation, the constituent entities of the Russian Federation, law enforcement practice, a critical study of the main results of scientific and analytical research related to the institutional support of inter-ethnic relations.

\section{Results and Discussion}

1. At the federal level, tasks and functions for assuring the implementation of National Policy have been repeatedly transferred from one federal executive body to another. Even now, there is no unanimity in understanding how government bodies should be built to implement tasks and functions in the field of interethnic relations, and how competence should be distributed so that no situations of "dilution" of responsibility arise and the effective implementation of the measures envisaged is ensured.

Proposals were repeatedly expressed to change the basic model of the National Policy institutional support in order to make it more centralized, simultaneously implying the strengthened influence of authorized federal bodies of state power and expanding their structure, the ideas of creating a ministry for interethnic relations, which would have its own territorial bodies, or strengthening Federal Agency for Ethnic Affairs (FADN), including through the creation of territorial bodies. In particular, once again the proposal to create the Ministry of Ethnic Affairs of the Russian Federation was voiced on October 14, 2020 at a joint session of the round table of the Public Chamber of the Kaluga Region and the Public Chamber of the Russian Federation on the subject "On actual issues of implementation of the Strategy of State National Policy of the Russian Federation through to 2025" [8]: it was assumed that this will allow us to deal at a new, higher quality level not only with issues of inter-ethnic relations, but also to work with Russian diasporas abroad.

2. Currently, planned activities for the National Policy implementation cover a significant number of participants, while the FADN does not have direct coordination powers. The Accounts Chamber of the Russian Federation, after analyzing the compliance of the goals, objectives, parameters (indicators) of the State Programme of the Russian Federation "The 
Implementation of the State National Policy" and the results of its implementation with the strategic planning documents in $2012-2018$ and the expired period of 2019, stated a lack of control and a low level of interaction between this State Programme participants. It was noted that the FADN, as the responsible implementer, does not provide the necessary coordination of this State Programme participants' actions; as a result, it does not allow to ensure proper control over the effective use of funds and the actual achievement of results [9].

In December 2018, significant amendments were introduced to the Strategy of State National Policy of the Russian Federation through to 2025, aimed, among other things, at improving public administration in this area: the emphasis was placed on the development of coordination mechanisms in the activities of public authorities and local government, optimization tools for interaction with civil society institutions, development of ethnocultural infrastructure (houses of friendship, centers of the national culture of the peoples of the Russian Federation, ethnic parks, ethnic villages, etc.). In addition, the provision defining the role of the Government of the Russian Federation and local self-government bodies was adjusted: if earlier it was envisaged that the implementation of the Strategy was carried out by the Government of the Russian Federation in cooperation with federal and regional government bodies, then according to the updated version of the Strategy shall be implemented by the Government of the Russian Federation, federal executive bodies, state power of the constituent entities of the Russian Federation, local government bodies in accordance with their competence.

In order to coordinate the activities of state bodies and local self-government bodies, public associations, scientific and other organizations in the implementation of the state national policy of the Russian Federation, the Interdepartmental Working Group on Interethnic Relations was established (although it was more correct to speak about the restoration of its activities, since the group has been established earlier, but had not convened meetings for several years). Without denying the effectiveness of the Interdepartmental Working Group as an institutional tool that ensures the coordinated activity of government bodies, it nevertheless seems that it cannot be considered sufficient to solve the existing issues of public administration in the field of inter-ethnic relations, including due to the operation format specifics.

It also seems expedient to provide direct coordination powers directly to the FADN, which has been entrusted already general functions to control the implementation of state national policy, including overseeing the implementation of the Strategy (the Interdepartmental Working Group should remain the main coordinating body).

3. The existing institutional framework for the National Policy implementation is built in such a way that the main "center of gravity" is not located at the federal, but at the regional and municipal levels: the state authorities of the constituent entities of the Russian Federation and local governments bear the main burden on the implementation of various measures within the framework of the national policy. In this regard, the effectiveness of the implementation of this direction of state policy largely depends on how well the work will be organized in the regions and municipalities

For a long time, the institutional mechanisms used to regulate inter-ethnic relations at the regional and municipal levels remained largely undeveloped and did not comply with the institutional framework of the federal level. The corresponding tasks and functions were often only casually mentioned when regulating the competence of individual state authorities of the constituent entities of the Russian Federation, while there was no clear regulation of the forms and procedures for interaction of bodies involved in the implementation of state ethnic policy. In this regard, federal government bodies began to undertake efforts aimed at improving regional institutional mechanisms for the implementation of national policy, building an institutional framework similar to that existing at the federal level (the process of harmonization of the institutional mechanism for the implementation of state policy affected 
not only public authorities. Thus, on November 27, 2019, the Government of the Russian Federation adopted the order on establishment the Federal State Budgetary Institution "House of the Peoples of Russia"; at the same time, FADN was instructed to develop guidelines for the creation and operation of houses of nationalities in the regions, which should be based on the experience of the Moscow House of Nationalities, that is, we are talking about creating a network of such institutions (now houses of friendship have been created in about a third of the constituent entities of the Russian Federation).

Thus Guidelines on topical issues of the State National Policy implementation, the formation of positive inter-ethnic and ethno-confessional relations in the local community, as well as on the identification and prevention of interethnic conflicts (approved by order of the FADN dated November 27, 2017 No. 133), a set of recommendations for the institutional mechanism formation of the National Policy implementation at the regional and municipal levels: the executive authorities of the constituent entities of the Russian Federation responsible for the implementation of the national policy should be subordinate to the deputy governor / deputy chairman of the government of the constituent entity of the Russian Federation as structural units - internal policy departments of the administrations of the heads of the constituent entities of the Russian Federation / relevant ministries (structures similar in functionality); the number of employees of the units responsible for the National Policy implementation should be determined based on regional characteristics and the range of topical issues in the field of national policy of the constituent entity of the Russian Federation; at the level of municipalities, an official responsible for work in the field of inter-national (inter-ethnic) and ethno-confessional relations must be in the position not lower than the deputy head of the municipal formation; it is necessary to develop interdepartmental interaction in the implementation of national policy, including through the creation of interdepartmental commissions, including representatives of all interested executive authorities, taking into account the strategic documents and programs adopted at the federal level, etc.

In January 2020, the Chief Executive Officers (heads of the supreme executive bodies of state power) of the constituent entities of the Russian Federation were recommended to take measures to increase the efficiency of the constituent entities of the Russian Federation activities and heads of municipalities formed under the Chief Executive Officers (heads of the supreme executive bodies of state power) of the constituent entities of the Russian Federation and other advisory bodies on issues of inter-ethnic and inter-religious relations [10].

4. Various bodies and officials are involved in the implementation of the national policy at the regional level. As a rule, the competence of the bodies involved in the National Policy implementation is delimited, but nevertheless, sometimes this is done very formally, as a result, the ownership of certain powers remains uncertain. The practice of a generalized enumeration of powers, tasks, functions, without distribution among the relevant bodies (including when listing the performers of certain activities), is preserved, which complicates the process of delimiting competence in practice. The forms and procedure for the interaction of bodies involved in the State National Policy implementation are not sufficiently regulated

Ensuring the State National Policy implementation in the constituent entities of the Russian Federation is carried out by the highest official of the constituent entity of the Russian Federation (the head of the supreme executive body of state power of the constituent entity of the Russian Federation); in practice, one of his deputies, who also heads the Advisory Board on Inter-Ethnic Relations, is often vested with appropriate powers.

The Advisory Board on Inter-Ethnic Relations to be established under the highest official of the constituent entity of the Russian Federation (the head of the highest executive body of state power of the constituent entity of the Russian Federation) or under the authorized executive body of the constituent entity of the Russian Federation, is a regional analogue of 
the Council for Interethnic Relations under the President of the Russian Federation. The literature emphasizes that the institutionalization of interaction on interethnic issues in consultative structures under the government is widely used in the modern world, that is, it is not something unusual or unique; it should be borne in mind that advisory bodies are only one of the structural elements of the interaction under consideration, they are supplemented, and sometimes replaced by other methods, forms and mechanisms of interaction [5].

The tasks and functions of such consultative and advisory bodies may be limited to issues of interethnic relations (for example, the Council for Inter-Ethnic Relations in the Kamchatka Territory, the Council for Inter-Ethnic Relations under the Governor of the Khabarovsk Territory), and also apply to the sphere of interfaith relations (in particular, the Council under the head of the administration (Governor) of Krasnodar Territory on Inter-Ethnic Relations and Interaction with Religious Associations, Council under the Head of the Republic of Adygea on Inter-Ethnic Relations and Interaction with Religious Associations); there is a practice of vesting advisory bodies with coordination functions.

At the moment, Councils for Inter-Ethnic Relations do not function in all constituent entities of the Russian Federation, while their status and scope of competence differ. Often, due to the parameters of activity set by regional regulatory legal acts, the possibilities of councils remain very limited, and the potential of such bodies is not fully utilized. Some councils are a permanent body (this allows them to respond quickly to situations related to the implementation of national policy), some are not. The consultative and advisory bodies include representatives of various public authorities, public organizations, the expert community, etc., which makes it possible to build a constructive direct dialogue between public authorities and civil society institutions, optimize the implementation of national policy, and timely identify existing problems. At the same time, it should be borne in mind that such bodies can meet very rarely (in the provisions governing their activities, you can find the wording "at least once a year or as needed"), the decisions taken are advisory in nature and in this regard do not always have a direct impact on the implementation of national policy in the subject of the Russian Federation. In addition, these bodies are often not included in the strategic planning mechanism in the field of interethnic relations, although this is expedient.

The existing experience in attracting councils to law-making activities (in a consultative and consultative format) is highly commendable; there is such experience in the Republic of Altai, where councils take part in the discussion of draft laws and other normative acts of this constituent entity of the Russian Federation concerning the rights and interests of ethnic communities. make proposals to amend the current legislation affecting the rights and interests of ethnic communities.

The main scope of tasks and functions in the field of inter-ethnic relations at the regional level is carried out by the authorized executive bodies of the constituent entities of the Russian Federation. In most cases, the tasks and functions in the field of inter-ethnic relations, including participation in the implementation of the Strategy of the State National Policy of the Russian Federation through to 2025, are carried out by executive authorities with broad competence (for example, in the Republic of Ingushetia - the Ministry of Foreign Relations, National Politics, Press and Information of the Republic of Ingushetia, in the Republic of Mordovia - the Ministry of Culture, National Policy and Archival Affairs of the Republic of Mordovia). In a number of constituent entities of the Russian Federation, special executive authorities have been created with competence limited precisely to the sphere of interethnic relations: for example, in the Republic of Dagestan, there is a Ministry for National Policy and Religious Affairs, in the Komi Republic - the Ministry of National Policy of the Komi Republic, in the Republic of North Ossetia-Alania - Ministry of the Republic of North Ossetia-Alania for national relations. The creation of a special executive body dealing exclusively with issues of national policy and interethnic relations is not an end in itself, but 
this approach seems to be quite justified for regions with a pronounced multi-ethnic and multi-confessional composition of the population, which are characterized by increased risks of inter-national and inter-ethnic conflicts.

The legislative (representative) body of state power of the constituent entity of the Russian Federation, as a rule, among the implementers of measures for the State National Policy implementation, is indicated in the context of legislative support for certain issues that need to be resolved. At the same time, it seems expedient to use more fully the potential of this body, primarily within the framework of regional parliamentary control; At the same time, it should be borne in mind that today the institution of regional parliamentary control is not sufficiently developed, the formation of organizational and legal mechanisms that ensure its functioning has not yet been completed in many regions. There are examples when the legislative (representative) body of a constituent entity of the Russian Federation formulated recommendations for improving the implementation of state ethnic policy. In particular, we are talking about the experience of the Republic of North Ossetia-Alania, where the Parliament, after hearing the relevant information from the Government, adopted a number of recommendations, not only to the Government, but also to local governments [11].

The consideration of the indigenous peoples' interests are ensured through the activities of public councils, councils of representatives of indigenous peoples under the state authorities of the constituent entities of the Russian Federation, with the help of coordination councils created in order to protect the original habitat and traditional way of life of the indigenous peoples of the Russian Federation, preserve their identity, as well as through the institution of plenipotentiaries for human rights.

At the regional level, there is a practice of creating the position of representative of indigenous peoples under the legislative (representative) body of state power of a constituent entity of the Russian Federation (in particular, the legislation of the Republic of Buryatia provides the position of an authorized representative of indigenous peoples of the Russian Federation in the People's Khural of the Republic of Buryatia). The introduction of such a position is intended to provide additional protection for the interests of indigenous small peoples, at the same time, the effectiveness of activities will be predetermined by the existing scope of powers, the possibility of influencing the legislative process (for example, the right to initiate legislation or the right to provide opinions on draft laws, one way or another affecting inter-national relations).

The creation of councils of representatives of indigenous minorities is a right of state authorities of the constituent entities of the Russian Federation, and not an obligation (Article 6 of the Federal Law of April 30, 1999, No. 82-FZ "On Guarantees of the Rights of Indigenous Peoples of the Russian Federation"). At the legislative level, it can be envisaged that in the event that an initiative is shown on the part of indigenous peoples, the creation of councils in the constituent entities of the Russian Federation where they live is mandatory [12].

The possible creation in the constituent entities of the Russian Federation the position of Indigenous Peoples Rights Commissioner is provided for in the Federal Law of October 6, 1999 No. 184-FZ “On General Principles of Organization of Legislative (Representative) and Executive Bodies of State Power of Subjects of the Russian Federation". Today, such a position exists, for example, in the Republic of Sakha (Yakutia), in the Kamchatka Territory, and the Krasnoyarsk Territory. A comparative analysis of the normative legal acts of the constituent entities of the Russian Federation, defining the status of ombudsmen for the rights of indigenous minorities, showed significant differences in the requirements for candidates for this position, the procedure for election (appointment), and the scope of competence. As a result, it can be stated that the effectiveness of the activities of the Indigenous Peoples 
Rights Commissioner, the level of protection they can provide, will be different in different constituent entities of the Russian Federation.

Within the literature, the opinion is expressed that one of the areas of improvement may be the creation of a structure coordinating the Indigenous Peoples Rights Commissioner activities in the state mechanism for the protection of rights and freedoms in the constituent entities of the Russian Federation, while emphasizing that such an administrative vertical is more expedient to create at the level of the Siberian and the Far Eastern Federal Districts, which include most of the territories of traditional residence of indigenous minorities. An alternative regulatory option that does not involve complicating the institutional framework is the unification of the basic requirements for a person applying for the position of the Indigenous Peoples Rights Commissioner, as well as the establishment of requirements for the participation of representatives of indigenous minorities in the procedure for his appointment. Some researchers point to the actualization of the issue of establishing the institution of the Human Rights Commissioner of the Russian Federation in connection with the process of specialization of the institution of the Commissioner. At the same time, it is possible to predict the difficulties of delimiting the competence of such an official with other federal government bodies that implement the tasks and functions in the field of interethnic relations.

In recent years, at the regional level, the practice of adopting normative legal acts regulating the procedure for interaction between state authorities of the constituent entities of the Russian Federation and the Indigenous Peoples Rights Commissioner has become widespread, which undoubtedly deserves a positive assessment. At the same time, in addition to simply listing the principles, main forms and areas of interaction, it seems expedient in such documents to regulate the procedure for involving representatives of indigenous peoples in decision-making, and not a single list, but for each area of interaction, if this is not regulated in other regulatory acts.

The species diversity of bodies created at the regional level in order to ensure the implementation of national policy and the fulfillment of tasks and functions in the field of inter-ethnic relations is not limited only to the above, but their example shows typical problems that arise in the institutional support of the National Policy implementation in the constituent entities of the Russian Federation.

An important role in the institutional framework of the State National Policy, especially in the process of stabilizing the situation, building confidence in the authorities and harmonizing the interests of different ethnic communities, is played by public chambers, the Human Rights Commissioner, Child Rights Commissioner, public councils under the executive authorities, providing both a mutual dialogue between national public associations, and their dialogue with authorities at all levels, etc. These bodies are involved in the development of decisions on issues of State National Policy, scientifically based projects and programs, plans for the State National Policy implementation, examination of management decisions in the field of inter-ethnic relations.

5. Scarcely ever is practical to clearly distribute the powers of public authorities to implement certain areas of National Policy, including due to existing legal gaps. For example, it has not yet been determined what is meant by social and cultural adaptation and integration of foreign citizens in the Russian Federation, in this regard, there is some uncertainty in determining the limits of the FADN's competence as a body engaged in the development and implementation of state policy, as well as regulatory legal regulation and provision of state services in the field of social and cultural adaptation and integration of foreign citizens in the Russian Federation. At the same time, there are difficulties in establishing a clear scope of powers of state authorities of the constituent entities of the Russian Federation and local governments for the social and cultural adaptation of foreign citizens. 
In this regard, it should be recalled that the powers of state authorities of the constituent entity of the Russian Federation in matters of joint jurisdiction, carried out by these bodies independently at the expense of the budget of the constituent entity of the Russian Federation (with the exception of subventions from the federal budget), include the authority to develop and implement measures aimed at social and cultural adaptation of migrants; the issues of local importance of urban and rural settlements include the creation of conditions for the implementation of measures aimed at the social and cultural adaptation of migrants, and the issues of local importance of municipal districts and urban districts - the development and implementation of measures aimed at ensuring the social and cultural adaptation of migrants.

6. It is necessary to more actively involve local governments in the development and adoption of decisions on issues related to the implementation of national policy. Currently, representatives of local self-government bodies are rarely included in the consultative and advisory bodies in the field of interethnic relations, created at the regional level, although, as noted by the head of the FADN, it is at the municipal level that all current work takes place [13].

\section{Conclusions}

1. Evaluating the decisions made in recent years at the state level aimed at optimizing the institutional mechanism for the National Policy implementation of national policy, it can be stated that the development of general model of public administration in the field of interethnic relations follows the path that provides:

strengthening the mechanisms of coordination and interaction of public authorities involved in the National Policy implementation;

formation of a uniform institutional framework in the field of inter-ethnic relations at the federal, regional and municipal levels, which implies, in particular, the creation of special consulting and advisory bodies; expanding the practice of interaction between public authorities and civil society institutions;

the use of strategic planning documents as the main regulator to streamline the interaction of all actors involved in the National Policy implementation;

an increase in the share of recommendatory acts adopted in order to exert regulatory influence on the state authorities of the constituent entities of the Russian Federation and local government, etc.

2. The work should continue to improve the efficiency of coordination mechanisms and interaction of all actors involved in the National Policy implementation. One of the possible options for such regulation may be the expansion of the powers of the Federal Agency for Ethnic Affairs through the vesting of direct coordinating powers (the main coordinating body should remain the Interdepartmental Working Group). Considering that within the National Policy framework, many diverse activities are being implemented, many of which are supervised by other federal executive bodies, it is advisable to substantively limit the coordination powers of the Federal Agency for Ethnic Affairs (for example, the agency could coordinate issues of social and cultural adaptation of foreign citizens in the Russian Federation and their integration into Russian society).

3. The existing institutional framework for the National Policy implementation is built in such a way that the main burden for the implementation of various activities within the framework of the national policy shall be borne by the public authorities at the regional and municipal levels. In this regard, the efficiency of the implementation of this state policy direction largely depends on how well the work will be organized in the regions and municipalities. Institutional instruments currently used at the regional and municipal levels are not always effective, including due to insufficient elaboration of regulatory legal acts that determine the procedure for the creation and functioning of the relevant public authorities. 


\section{References}

1. The State Duma Publication, Analysis of Russian and foreign legal framework, international legislation and regulatory enforcement on protection of rights of indigenous peoples of the North, Siberia and the Far East of the Russian Federation (2019)

2. A.Yu. Polunov, Issues of state national policy implementation in constituent entities of the Russian Federation: Guidance Materials (2018)

3. T.V. Zametina, Leningrad legal journal, 2 (36), 215 (2014)

4. O.V. Kolesnikova, Advanced topics of Russian law, 9 (2019)

5. K.A. Sulimov, S.R. Titova, Perm University Herald. Political sciences, 4, 151 (2016)

6. T.Ya. Khabrieva, A.A. Klishas, Specific commentary on the law of the Russian Federation on amendment to the Constitution of the Russian Federation dated March 14, 2020. No. 1-FKZ "On Improvement of Separate Organization Issues of Regulation and Functioning of Public Authority"(2020)

7. The Decree of the President of the Russian Federation dated December 19, 2012 No. 1666 "On Strategy of State National Policy of the Russian Federation through to 2025"

8. Actual objectives of National Policy Strategy were discussed in Kaluga, https://regnum.ru/

9. Official website of the Accounts Chamber of the Russian, http://www.ach.gov.ru/

10. List of instruction after the meeting of council for inter-ethnic relations (approved by the President of the Russian Federation on January 16, 2020, No. Pr-71)

11. The resolution of the Parliament of the Republic of North Ossetia-Alania dated May 31, 2018 No. 266 / 12-6 "On information from the Government of the Republic of North Ossetia-Alania "On the Implementation of the State Program of the Republic of North Ossetia-Alania "Development of Inter-Ethnic Relations in the Republic of North Ossetia-Alania" 2014-2018 as part of the Strategy of the State National Policy of the Russian Federation through to 2025"

12. L.V. Andrichenko, E.E. Nikitina, I.V. Plyugina et al, Analysis of Russian and foreign legal framework, international legislation and regulatory enforcement on protection of rights of indigenous peoples of the North, Siberia and Far East of the Russian Federation (2019)

13. National politics starts locally, https://ugra-news.ru/ 